
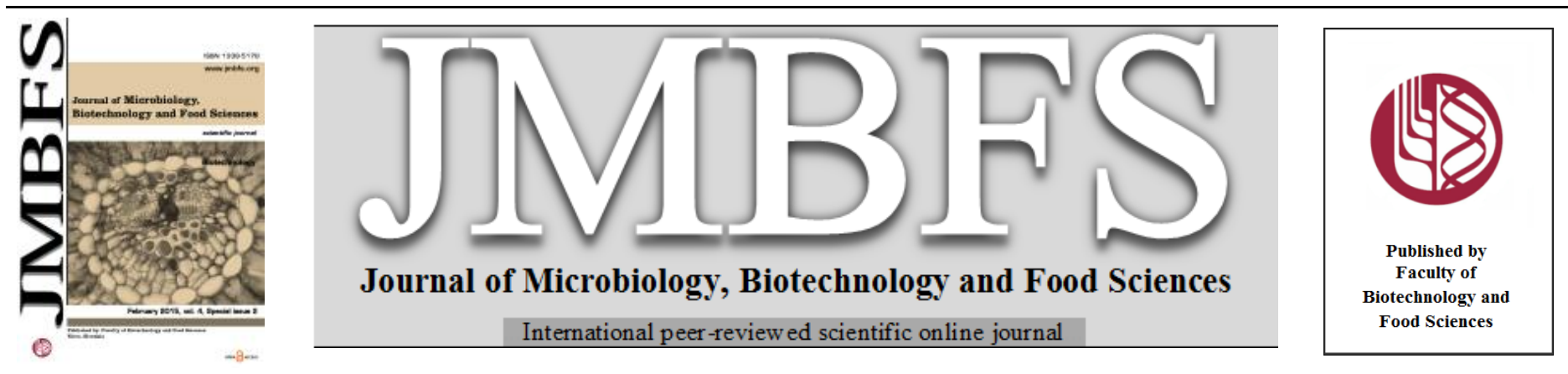

\title{
POLYAMINE BIOSYNTHESIS REGULATORS: POTENT MODULATORS OF HERBICIDE STRESS IN SPRING BARLEY (HORDEUM VULGARE)
}

\section{Pavol Trebichalský, Ján Tomáš, Luboš Harangozo, Bajčan Daniel, Alena Vollmannová}

Address(es): Ing., PhD., Pavol Trebichalský,

Faculty of Biotechnology and Food Sciences, Department of Chemistry, Slovak University of Agriculture, Tr. A. Hlinku 2, 949 76, Nitra, Slovak Republic, tel. $+42137 / 6415376$.

*Corresponding author: pavol.trebichalsky@uniag.sk

doi: 10.15414/jmbfs.2015.4.special2.114-115

\section{ARTICLE INFO}

Received 20.11.2014

Revised 2. 12. 2014

Accepted 18. 12. 2014

Published 2. 2. 2015

Regular article

OPEN $\partial_{\text {ACCESS }}$

\section{ABSTRACT}

Regulators of polyamine biosynthesis, such as 1,3-propylene diamine and $\gamma$-aminobutyric acid, are involved in reducing stress in plants. Triazine herbicide application on spring barley plants under conditions of pot experiment reduced grain yield by $1.8 \%$. After application of mixtures with regulators of polyamine biosynthesis a decline of grain yield was obtained (statistically not significant, by 7-15\%), when compared to variant with only herbicide applied. Triazine herbicide and mixtures with regulators of polyamine biosynthesis reduced one thousand grain weight, slightly increased the number of grains in a spike. Therefore, it would be more efficient to use the regulators of polyamine synthesis independently, not together with the herbicide before tillering.

Keywords: Triazine herbicide, cyanazine, polyamines

\section{INTRODUCTION}

Pesticides are used throughout the world as mixtures called formulations. They contain adjuvants, which are often kept confidential and are called inerts by the manufacturing companies, plus a declared active principle, which is usually tested alone (Mesnage, 2014). Herbicides of the triazine, phenolic and urea families, which bind to the D1 protein, inhibit photosystem II (PSII), and block electron transfer to the plastoquinone pool (Ramel, 2007; Rutherford and Krieger-Liszkay, 2001), thus causing the production of triplet chlorophyll and singlet oxygen $\left({ }^{1} \mathrm{O}_{2}\right)$. In cyanobacterial cells, ${ }^{1} \mathrm{O}_{2}$ has been shown to cause direct photodamage to PSII and D1 protein and to prevent PSII repair by suppressing elongation of D1 protein (Nishiyama, 2004). Furthermore, ${ }^{1} \mathrm{O}_{2}$ may generate other reactive oxygen species (ROS), such as hydroxyl radical (HO') (Rinalducci, 2004).

Polyamines are polycations and thus one of their main features is to interact with negatively charged molecules, such as DNA, RNA or proteins. Given their promiscuity in binding other molecules, they are involved in many functions, mostly linked with cell growth, survival and proliferation. Three polyamines, putrescine, spermidine and spermine, are part of the very tightly regulated polyamine metabolic pathway. Polyamines are the subject of intensive research in order to elucidate their functions and involvement in physiology. Polyamines are important players in plant growth, stress and disease resistance (Hussain, Ahmad and Siddique, 2011).

Several studies have shown that polyamine accumulation occurs under abiotic stresses including drought, salinity, extreme temperature, paraquat, hypoxia, UV$\mathrm{B}$, heavy metals, mechanical wounding and herbicide treatment (Groppa and Benavides, 2008; Pang et al., 2007).

The goal of our experiment was to observe the influence of triazine herbicide and its mixtures with polyamine biosynthesis regulators on the yield and grain quality of spring barley.

\section{MATERIAL AND METHODS}

In pot experiment $6 \mathrm{~kg}$ of substrate (soil : sand - $4: 2$ ) was weighed. Analyses done in soil used in experiment are shown in Table 1. It was sown 30 plants which were thinned into 20 pieces after post-emergence. At the phase of early tillering plants were foliar treated (after 25 days) in the control treatment with the water (Table 2), in other variants with triazine herbicide alone (the active ingredient is cyanazine with chemical formula 2-(4-chloro-6-ethylamino-1,3,5triazin-2-ylamino)-2-methylpropiononitrile), or its mixture with $\gamma$-aminobutyric acid (GABA) with dose 500 g.ha ${ }^{-1}$, in another variant with 1,3-propylenediamine
(PDA) with dose of $59.2 \mathrm{~g} \mathrm{ha}^{-1}$, and in last variant with the PDA in the amount of 29,6 g.ha $^{-1}$. The plants were watered with constant volume in all pots Once fully ripened, the plants of spring barley were prepared for biometric determination of the production parameters (grain yield, number of productive spikes, thousand grain weight, and number of grains in a spike).

The data were statistically analysed by variance analysis (ANOVA) using the statistical programme Statistica.

Table 1 Characteristics of soil used in pot experiment

\begin{tabular}{cl|cccc}
\hline \multirow{2}{*}{$(\mathrm{pH} / \mathrm{KCl})$} & $\begin{array}{l}\text { Humus } \\
\text { content } \\
\end{array}$ & \multicolumn{4}{c}{ Nutrients $\left(\mathrm{mg} \cdot \mathrm{kg}^{-1}\right)$} \\
\cline { 5 - 6 } & $\mathrm{N}_{\mathrm{an}}$ & $\mathrm{P}$ & $\mathrm{K}$ & $\mathrm{Mg}$ \\
\cline { 5 - 6 } $6.07-7.03$ & 2.34 & 8.7 & 54.3 & 178.35 & 407.8 \\
\hline
\end{tabular}

Table 2 Variants of the pot experiment

\begin{tabular}{|c|c|}
\hline $\begin{array}{l}\text { VARIANT } \\
\text { NUMBER }\end{array}$ & FOLIAR TREATMENT \\
\hline 1 & $\begin{array}{c}\text { Control: } \\
9,0 \mathrm{ml} \text { water }\end{array}$ \\
\hline 2 & $\begin{array}{l}\text { Triazine herbicide } 0,51 . \mathrm{ha}^{-1} \text { : } \\
1,0 \mathrm{ml} \text { water solution of triazine herbicide }+8,0 \mathrm{ml} \text { water }\end{array}$ \\
\hline 3 & $\begin{array}{l}\text { Triazine herbicide } 0,51 \cdot \mathrm{ha}^{-1}+\text { GABA } 500 \mathrm{~g} \cdot \mathrm{ha}^{-1}: \\
1,0 \mathrm{ml} \text { water solution of triazine herbicide }+4,7 \mathrm{ml} 20 \mathrm{mM} \\
\text { solution GABA }+3,3 \mathrm{ml} \text { water }\end{array}$ \\
\hline 4 & $\begin{array}{c}\text { Triazine herbicide } 0,51 \cdot \mathrm{ha}^{-1}+\text { PDA } 59,2 \mathrm{~g}^{-\mathrm{ha}^{-1}} \text { : } \\
1,0 \mathrm{ml} \text { water solution of triazine herbicide }+3,8 \mathrm{ml} 2 \mathrm{mM} \\
\text { solution PDA }+4,2 \mathrm{ml} \text { water }\end{array}$ \\
\hline 5 & $\begin{array}{l}\text { Triazine herbicide } 0,51 \cdot \mathrm{ha}^{-1}+\text { PDA } 29,6 \mathrm{~g}^{-h^{-1}} \text { : } \\
1,0 \mathrm{ml} \text { water solution of triazine herbicide }+1,9 \mathrm{ml} 2 \mathrm{mM} \\
\text { solution PDA }+6,1 \mathrm{ml} \text { water }\end{array}$ \\
\hline
\end{tabular}

Abbreviations:

PDA - 1,3-propylene diamine

GABA - $\gamma$-aminobutyric acid

\section{RESULTS AND DISCUSSION}

The treatment of plants by triazine herbicide (as the application of herbicide alone) reduced grain yield by $1.8 \%$ (Table 3 ). Mixtures of triazine herbicide with the regulators of polyamine biosynthesis compared to the application of herbicide alone reduced its yield-forming effect (also in a variant compared with the 
control). After application of mentioned mixtures there was obtained statistically non-significant lower grain yield (by 7-15\%) when compared to the variant of triazine herbicide application (except for variants with PDA, where we observe the statistical significance). It can be concluded that the presence of regulators in mixtures with triazine herbicide had not a beneficial effect on grain yield.

The herbicide induced changes, predominantly in lipid peroxidation (LPO) intensity, superoxide anion $\mathrm{O}^{2(-)}$ generation, total antioxidant activity (AOA), catalase (CAT) and ascorbate peroxidase (APOX) activity, although the response by plants was nonlinear and depended on the herbicide concentration and duration of treatment (Lukatkin, 2013).

For treatment of cultivated plants are also used so-called 'safeners' which are an important group of agrochemicals used extensively in cereals to protect crops from damage caused by selective herbicides without compromising weed contro efficacy (Davies and Caseley, 1999; Edwards et al., 2005; Hatzios, 2003; Hatzios and Burgos, 2004). The mechanism of safener action most widely accepted is that these chemicals enhance crop tolerance by inducing the expression of proteins (involved in the metabolism of herbicides, thus accelerating their detoxification (Davies and Caseley, 1999; Hatzios and Burgos, 2004). Amongst these 'safened' enzymes, the best studied are the glutathione transferases (GSTs) which catalyze the conjugation of herbicides with the endogenous tripeptide glutathione (Cummins et al., 1997; Davies and Caseley, 1999; DeRidder and Goldsbrough, 2006). Such conjugation has been demonstrated in barley (Scalla and Roulet, 2002). The application itself triazine herbicide also decreased (statistically non-significant) number of productive spikes (Table 3). Number of productive tillers was in terms of yield-forming parameter in the closest relationship with grain yield of spring barley - this relationship is understandable, because foliar application is done at the beginning of tillering. Differences in the number of tillers were recorded as statistically significant only after application of higher doses of PDA in combination with herbicide. Triazine herbicide and its mixtures (Table 3) reduced one thousan grain weight, slightly increased the number of grains in a spike. Differences in the number of grains in a spike and one thousand grain weight are statistically not significant in variants except for the variant with GABA.

The plants of spring barley in a relatively favourable moisture conditions and with soil substrate tolerate relatively well short-term stress effects of the herbicide. Barley plants together with plants of oat, as well as wheat are tolerant to the herbicide chlorsulfuron, which metabolize to polar molecules that are inactive (Sweetser et al., 1982).

Therefore, it would be more efficient use of regulators of polyamine synthesis independently, not together with the herbicide before tillering, but in the later stages of ripening grain, whereas according to the known effects of polyamines are themselves able to inhibit senescence indicated increase protease activity (Kaur-Sawhney et al., 1982).

Table 3 Parameters of yield-forming process in barley grain from pot experiment

\begin{tabular}{l|c|c|c|c}
\hline Variant & $\begin{array}{c}\text { Grain weight } \\
(\mathrm{g})\end{array}$ & $\begin{array}{c}\text { Number of } \\
\text { productive } \\
\text { spikes }\end{array}$ & $\begin{array}{c}\text { One thousand } \\
\text { grain weight } \\
(\mathrm{g})\end{array}$ & $\begin{array}{c}\text { Number of } \\
\text { grain in a } \\
\text { spike }\end{array}$ \\
\hline 1 & $26,2^{\mathrm{B}}$ & $34,0^{\mathrm{B}}$ & $47,5^{\mathrm{AB}}$ & $16,2^{\mathrm{A}}$ \\
2 & $25,7^{\mathrm{B}}$ & $33,5^{\mathrm{B}}$ & $46,1^{\mathrm{B}}$ & $16,7^{\mathrm{A}}$ \\
3 & $23,8 \mathrm{~A}^{\mathrm{BC}}$ & $31,8^{\mathrm{B}}$ & $44,7^{\mathrm{A}}$ & $16,8^{\mathrm{B}}$ \\
4 & $21,7^{\mathrm{A}}$ & $26,3^{\mathrm{A}}$ & $46,9^{\mathrm{AB}}$ & $17,6^{\mathrm{AB}}$ \\
5 & $21,9^{\mathrm{C}}$ & $30,4^{\mathrm{AB}}$ & $46,1^{\mathrm{AB}}$ & $15,8^{\mathrm{A}}$ \\
\hline
\end{tabular}

Capital letters in table stand for statistical significance in columns $(\mathrm{P}<0.01)$ - their conformity means that the values are statistically non-significant and different letters characterize statistical significance.

\section{CONCLUSION}

The application of triazine herbicide alone contributed to a decline in yield of barley grain. Polyamine biosynthesis regulators also did not have the positive impact on yield of grain, accurately even more negative when compared to the variant where the herbicide was applied alone. The polyamine biosynthesis regulators also either reduced or directly did not affect the values of one thousand grains weight. But their application positively influenced the number of grains in a spike (except for the variant with the herbicide with dose 29,6 g.ha ${ }^{-1}$ PDA).

Acknowledgement: This work was supported by grants VEGA 1/0724/12.

\section{REFERENCES}

CUMMINS, I., COLE, D.J., EDWARDS, R. 1997. Purification of multiple glutathione transferases involved in herbicide detoxification from wheat (Triticum aestivum L.) treated with the safener fenchlorazole-ethyl. Pesticide Biochemistry and Physiology, 59, 35-49. http://dx.doi: 10.1006/pest.1997.2308. DAVIES, J., CASELEY, J.C. 1999. Herbicide safeners: a review. Pesticide Science, 55, 1043-1058. $\quad$ http://dx.doi: 10.1002/(SICI)10969063(199911)55:11<1043::AID-PS60>3.0CO;2-L.
DeRIDDER, B.P., GOLDSBROUGH, P.B. 2006. Organ-specific expression of glutathione S-transferases and the efficacy of herbicide safeners in Arabidopsis. Plant Physiology, 140, 167-175. http://dx.doi.org/10.1104/pp.105.067199.

EDWARDS, R., BRAZIER-HICKS, M., DIXON, D.P., CUMMINS, I. 2005 Chemical manipulation of antioxidant defences in plants. Advances in Botanical Research, 42, 1-32. http://dx.doi: 10.1016/S0065-2296(05)42001-7.

GROPPA, M.D., BENAVIDES, M.P. 2008. Polyamines and abiotic stress: recent advances. Amino Acids, 34, 35-45. http://dx.doi:10.1007/s00726-007-0501-8.

HATZIOS, K.K. 2003. Herbicide safeners: effective inducers of plant defense gene-enzyme systems. Phytoparasitica, 31, 3-7. http://dx.doi 10.1007/bf02979761.

HATZIOS, K.K., BURGOS, N. 2004. Metabolism-based herbicide resistance: regulation by safeners. Weed Science, 52, 454-467. http://dx.doi: 10.1614/p2002 $168 \mathrm{c}$.

HUSSAIN, S.S., ALI, M., AHMAD, M., SIDDIQUE, K.H.M. 2011. Polyamines: Natural and engineered abiotic and biotic stress tolerance in plants. Biotechnology Advances, 29, 300-311. http://dx.doi: 10.1016/j.biotechadv.2011.01.003.

KAUR-SAWHNEY, R., SHIH, L., GALSTON, A. 1982. Relation of polyaminebiosynthesis to the initiation of sprouting in potato tubers. Plant Physiology, 69 411-415. http://dx.doi: 10.1104/pp.69.2.411.

LUKATKIN, A.S., GAR'KOVA, A.N., BOCHKARJOVA, A.S., NUSHTAEVA, O.V., TEIXEIRA DA SILVA, J.A. 2013. Treatment with the herbicide TOPIK induces oxidative stress in cereal leaves. Biochemistry and Physiology, 105(1) 44-9. http://dx.doi: 10.1016/j.pestbp.2012.11.006

MESNAGE, R., DEFARGE, N., SPIROUX DE VENDÔMOIS, J., SÉRALINI, G.E. 2014. Major pesticides are more toxic to human cells than their declared active principles. BioMed Research International, 2014, 1-8 http://dx.doi.org/10.1155/2014/179691.

NISHIYAMA, Y, ALLAKHVERDIEV, S.I., YAMAMOTO, H., HAYASHI, H MURATA, N. 2004. Singlet oxygen inhibits the repair of photosystem II by suppressing the translation elongation of the D1 protein in Synechocystis sp. PCC 6803. Biochemistry, 43, 11321-11330, http://dx.doi: 10.1021/bi036178q.

PANG, X.M., ZHANG, Z.Y., WEN, X.P., BAN, Y., MORIGUCHI, T. 2007 Polyamine, all-purpose players in response to environment stresses in plants. Plant Stress, Croydon : CPI Group (UK) Ltd, CRO 4YY, p. 173-188. ISBN-13 9781780642734.

RAMEL, F., SULMON, C., CABELLO-HURTADO, F., TACONNAT, L., MARTIN-MAGNIETTE, M.L., RENOU, J.P., AMRANI, A., COUÉE I.GOUESBET G. 2007. Genome-wide interacting effects of sucrose and herbicide-mediated stress in Arabidopsis thaliana: novel insights into atrazine toxicity and sucrose-induced tolerance. BMC Genomics, 8, 450. http://dx.doi:10.1186/1471-2164-8-450.

RINALDUCCI, S., PEDERSEN, J.Z., ZOLLA, L. 2004. Formation of radicals from singlet oxygen produced during photoinhibition of isolated light-harvesting proteins of photosystem II. Biochimica et Biophysica Acta (BBA) Bioenergetics, 1608, 63-73. http://dx.doi: 10.1016/j.bbabio.2003.10.009

RUTHERFORD, A.W., KRIEGER-LISZKAY, A. 2001. Herbicide-induced oxidative stress in photosystem II. Trends in Biochemical Sciences, 6, 648-653 http://dx.doi: 10.1016/S0968-0004(01)01953-3.

SCALLA, R., ROULET, A. 2002. Cloning and characterization of a glutathione S-transferase induced by a herbicide safener in barley (Hordeum vulgare) Physiologia Plantarum, 116, 336-344. http://dx.doi: 10.1034/j.1399 3054.2002.1160308.x

SWEETSER, P.B. SCHOW, G.S, HUTCHISON, J.M. 1982. Metabolism of chlorsulfuron by plants: Biological basis for selectivity of a new herbicide for cereals. Pesticide Biochemistry and Physiology, 17, 18-23. http://dx.doi:.org/10.1016/0048-3575(82)90121-3.

TAYLOR, V.L, CUMMINS, I, BRAZIER-HICKS, M, EDWARDS, R. 2013 Protective responses induced by herbicide safeners in wheat. Environmental and $\begin{array}{lll}\text { Experimental } & \text { Botany, } & \text { 93-99. }\end{array}$ http://dx.doi:10.1016/i.envexpbot.2011.12.030. 